Journal of Applied Pharmaceutical Science Vol. 5 (10), pp. 006-011, October, 2015

Available online at http://www.japsonline.com

DOI: 10.7324/JAPS.2015.501002

ISSN 2231-3354 (cc) BY-NC-SA

\title{
Chemical Composition and in vitro Antibacterial Activity of the Essential Oils of the Leaves, Resin and Stem-Barks of Dacryodes edulis (G. Don) H. J Lam growing in Cameroon on Diarrhea Associated Strains
}

\author{
Sara Honorine RIWOM ${ }^{1}$, Florentine M-C NDOYE FOE ${ }^{2 *}$, Maximilienne Ascension NYEGUE ${ }^{1,2,3}$, Reskingjoe AMBE \\ $\mathrm{WANKI}^{2}$, Steve VOUNDI Olugu ${ }^{1}$, François-Xavier ETOA ${ }^{1}$ \\ ${ }^{1}$ University of Yaoundé I, Department of Microbiology, Laboratory of Microbiology, PO Box 812 Yaoundé -Cameroon. ${ }^{2}$ University of Yaoundé I, \\ Department of Biochemistry, Laboratory of Phytobiochemistry and Medicinal Plant Study, PO Box 812 Yaoundé- Cameroon. ${ }^{3}$ Equipe de Recherche "Glyco \\ et nanovecteurs pour le criblage" Institut des Biomolécules Max Mousseron (IBMM), Faculté de Pharmacie, 15 avenue Charles Flahault, Bâtiment E 2 eme \\ étage, BP 1449134093 Montpellier-France.
}

\author{
ARTICLE INFO \\ Article history: \\ Received on: 21/07/2015 \\ Revised on: 14/08/2015 \\ Accepted on: 11/09/2015 \\ Available online: 28/10/2015 \\ Key words: \\ Dacryodes edulis, Essential \\ oil, Chemical composition, \\ Antibacterial activity, \\ Diarrhea.
}

\begin{abstract}
The aim of this work was to determine the chemical profile and assess in vitro the antibacterial activity of the leaves, resin and stem-barks of Dacryodes edulis. The essential oils were analyzed simultaneously by Gas Chromatography and Gas Chromatography coupled to Mass Spectrometry. Agar diffusion well and microdilution methods were used to assay the antibacterial activity. The resin essential oil contained $p$-cymene $(30.32 \%), \alpha$ thujene $(28.58 \%), \alpha$-phellandrene $(27.14 \%)$ and $\beta$-phellandrene $(10.16 \%)$ as the main components; the stembarks essential oil had as abundant components $p$-cymene (35.14\%), trans-carveol (22.60\%), $\alpha$-thujene (14.86\%), $\beta$-phellandrene (8.65\%) and $\beta$-elemene (5.22\%). The leaves essential oil was distinct with elemol $(29.22 \%)$, caryophyllene oxide (15.26\%), trans-carveol $(11.80 \%)$ and spathulenol $(6.28 \%)$ as major components. The leaves essential oil was the most active with MIC and MBC value of $18.75 \mathrm{mg} / \mathrm{mL}$ on B. cereus; the most susceptible strain. The stem-barks essential oil had a MIC of $50 \mathrm{mg} / \mathrm{mL}$ and MBC of $100 \mathrm{mg} / \mathrm{mL}$ on all the strains meanwhile the resin essential oil had a bacteriostatic effect at $200 \mathrm{mg} / \mathrm{mL}$. Based on these results, it emanates that the essential oils of $D$. edulis represent a potential source of antibacterial substances.
\end{abstract}

\section{INTRODUCTION}

Diarrhea is defined as having loose or watery stools at least three times per day, or more frequently than normal for an individual. It remains the second leading cause of death among children under five worldwide with a surpassing six million deaths in 2012 (IVAC, 2013). The probability of a sub-Saharan African to develop diarrhea is $39.1 \%$ as oppose to $7.2 \%$ in developed countries (WHO, 2006). Some of the dreadful complications of diarrhea include severe dehydration, loss of weight, impaired nutrition absorption, retarded growth and recurrent infections. In the absence of proper health care, it may lead to serious complications such as the life threatening hemolytic uremic syndrome characterized by thrombocytopenia,

\footnotetext{
* Corresponding Author

Email: mailid:chantfoe@yahoo.com
}

hemolytic uremia and kidney failure (Kouitcheu et al., 2013). Antibiotics have been the cornerstone to diarrhea. However, the emergence of multi-drug resistant strains partly due to the indiscriminate use of antimicrobial drugs exerts a huge pressure on antibiotherapy (Ahmad et al., 1998).

The present strategy used to circumvent the problem of microbial resistance to antibiotics therefore involves the search for new antimicrobial substances from plant origin (Clark, 1996).

Medicinal plants have a long history of use and their use is widespread in both developing and developed countries. According to a report of the World Health Organization (WHO), $80 \%$ of the world populations rely mainly on traditional therapies which involve the use of plant extracts or their active substances (WHO, 1993). Essential oils (EO) have been the target bioactive substances of plant origin in recent times. 
Several research works confirm that they are endowed with antimicrobial, antioxidant and anti-inflammatory properties among others (Nyegue, 2006; BioactiplantBase, 2015). These properties are most often due to the fraction of $\mathrm{EO}$ contained in the plant (Hulin et al., 1998; Ghost et al., 2008). The works of Ndoye, 2001; Nyegue, 2006 prove that the Cameroonian flora is gifted in medicinal and aromatic plants rich in EO Dacryodes edulis is one of the EO bearing plants belonging to the family of Burseraceae that has a long history in folk medicine. It is a small to mediumsized tree reaching 20-25 m high (Ajibesin et al., 2011).

Different parts of the plant are used in different parts of Africa in the treatment of various ailments. The decoction of the leaves is employed to relieve certain disorders of the digestive tract, toothache and earache. The leaves and stem-barks are used to cure dysentery and anaemia (Ayuk et al., 1999). The resin from the bark heals scars and other skin diseases in Nigeria (Burkill, 1985). The leaves are also reported to be employed in the remedy of skin problems such as ringworm, scabies and rashes (Ajibesin $e t$ al., 2011).

Most of the works carried out so far on the different parts of this plant are focused on the extracts with very few centered on the EO. The chemical profiles of the leaves, stem-barks, root-barks and fruits EO from Nigeria have been reported (Onocha et al., 1999; Siluo et al., 2013) while (Obame et al., 2008) reported the antibacterial activity of the resin EO from Gabon.

To the best of our knowledge, there has been no documented report on the chemical composition and antibacterial activity of the leaves, stem-barks and resin EO native to Cameroon against diarrhea strains. It is in this regard that we saw the necessity to determine the chemical constituents of the EO of $D$. edulis and investigate their antibacterial activity.

\section{MATERIAL AND METHODS}

\section{Plant material}

The plant material was harvested in February 2013 from the Centre Regional Delegation of Agriculture at Etoug-Ebe Yaoundé. The plant was identified as Dacryodes edulis (G. DON) H. J Lam at the National Herbarium of Cameroon by comparison with voucher number $55498 \mathrm{NHC}$.

\section{Bacterial strains}

The antibacterial effect was tested on a panel of bacterial isolates including two Gram positive: Staphylococcus aureus and Bacillus cereus and three Gram negative Escherichia coli, Salmonella typhi and Shigella spp bacteria. All isolates were obtained from the Laboratory of Microbiology of the University of Yaoundé I.

\section{Essential oil extraction}

The fresh leaves were washed with tap water to remove the dust. The moisture-free fresh leaves were chopped into small pieces, ground in a wooden mortar and pestle. In a similar manner, the fresh stem-barks were cleaned by scabbing off the dead cells on the barks, ground in a wooden mortar and pestle. Resin was obtained by making incisions on the trunk of the plant. $220 \mathrm{~g}$ (resin), $500 \mathrm{~g}$ (stem-barks) and $500 \mathrm{~g}$ (leaves) were subjected to hydrodistillation for 3 hours (resin) and 4 hours (stem-barks and leaves) using a Clevenger-type apparatus as adapted by Nyegue 2006; Agnaniet et al., 2011. The limpid oil obtained was separated from the hydrosol by decantation, dried over anhydrous sodium sulphate, filtered and stored in amber glass vials and stored in the dark at $4{ }^{\circ} \mathrm{C}$ (AFSSAPS, 2008 ; AFNOR, 2007) prior to chemical analyses and bioassay tests

\section{DETERMINATION OF THE CHEMICAL COMPOSITION OF THE ESSENTIAL OILS}

\section{Gas Chromatography}

The GC were carried out on a Variant CP 3380 gas chromatograph equipped with a flame ionization detector (FID) adjusted at $250^{\circ} \mathrm{C}$ coupled to two types of apolar columns (silica capillary): polar HP-5 J and W (Agilent (5\%-phenyl-95\% methyl polysiloxane) of capillary column $30 \mathrm{~m} \times 0.25 \mathrm{~mm}$ thickness and film thickness of $0.25 \mu \mathrm{m}$ ) and Supelcowax 10 (polyethylene glycol, Supelco Inc, Bellfonte, PA) fused capillary (internal diameter $30 \mathrm{~m} \times 0.25 \mathrm{~mm}, 0.25 \mu \mathrm{m}$ film thickness). Nitrogen was the carrier gas used at a constant flow rate of $0.8 \mathrm{~mL} / \mathrm{min}$ with injector regulated in split mode at $220^{\circ} \mathrm{C}$. The exit ratio was $1: 100$ $(0.1 \mu \mathrm{L}$ of pure $\mathrm{EO})$.

The injector temperature was $220{ }^{\circ} \mathrm{C}$ while that of the detector was $250{ }^{\circ} \mathrm{C}$. The temperature was then programmed at $50{ }^{\circ} \mathrm{C}$ to $200{ }^{\circ} \mathrm{C}$ at a ramp of $5{ }^{\circ} \mathrm{C} / \mathrm{min}$ and then maintained at 200 ${ }^{\circ} \mathrm{C}$ for 10 minutes: The entire set-up was coordinated by a computer system with the COPPASS software that ensured its functioning and follow-up of the chromatographic analyses from which quantitative data were obtained from FID area percent data.

\section{Gas Chromatography coupled to Mass Spectrometry}

The GC-MS was performed on a gaseous phase chromatograph using a Hewlett-Packard (GC 5890 series II) equipped with a HP-5(5\% phenyl-95\% methyl polysiloxane) fused capillary silica column (internal diameter of $30 \mathrm{~m} \times 0.25 \mathrm{~mm}$, film thickness of $0.25 \mu \mathrm{m}$ ) interfaced with another fused silica capillary DB-Wax (internal diameter of $30 \mathrm{~m} \times 0.25 \mathrm{~mm}, 0.25 \mu \mathrm{m}$ film thickness). The mass detector was of the quadrupole Model 5972 and the following conditions were used: ionization energy was $70 \mathrm{eV}$, column temperature programmed from $50{ }^{\circ} \mathrm{C}$ to $200{ }^{\circ} \mathrm{C}$, ramp of $5{ }^{\circ} \mathrm{C} / \mathrm{min}$ and first maintained at $50{ }^{\circ} \mathrm{C}$ for 2 minutes. The injection and MS transfer line temperatures were fixed at $220{ }^{\circ} \mathrm{C}$ and $180^{\circ} \mathrm{C}$ respectively.

Helium was used as the carrier gas at a flow rate maintained at $0.6 \mathrm{~mL} / \mathrm{min}$; inlet: split, $1: 10(1 \mu \mathrm{L}$ of a 10:100 $\mathrm{CH}_{2} \mathrm{Cl}_{2}$ solution), ionization voltage of $70 \mathrm{eV}$; electron multiplier $1460 \mathrm{eV}$, mass scan range 35-300 a.m.u, scan rate $2.96 \mathrm{scan} / \mathrm{s}$. Injection of $0.1 \mu \mathrm{L}$ of pure EO. The percentage composition of the 
EO was computed by the normalization method from the GC-FID peak areas, assuming an identical mass response factor for all compounds. A series of $n$-alkanes were used as reference points. The identification of the EO components was based on comparison of their relative retention index with published data in the literature and by matching their mass spectra with these published data (Adams, 2012).

\section{ANTIBACTERIAL ACTIVITY}

\section{Susceptibility Test}

The susceptibility of the bacterial strains to the EO was investigated as described by Valgas et al. (2007). Overnight cultures of the bacterial strains were spread on sterile MuellerHinton agar. With the aid of a sterile $6 \mathrm{~mm}$ cork borer, four equally spaced wells were bored in the agar plate with a fifth well at the center of the plate. Stock solutions of the EO were prepared by dissolving each $\mathrm{EO}$ in $10 \%$ tween-40 to a final concentration of $100 \mathrm{mg} / \mathrm{mL} .50 \mu \mathrm{L}$ of each EO was then introduced into 3 of the 5 wells.

The fourth well was filled with $50 \mu \mathrm{L}$ of $10 \%$ tween- 40 while the central well was filled with $20 \mu \mathrm{L}$ of the standard antibiotic (gentamicin $0.5 \mathrm{mg} / \mathrm{mL}$ ) to serve as negative and positive controls respectively. The test was carried out in triplicate, incubated for 24 hours at $37{ }^{\circ} \mathrm{C}$ and examined for zones of inhibition. The diameter of the zone of inhibition was measured using a sliding caliper $(\mathrm{mm})$ and the mean considered as the inhibition diameter.

\section{Determination of the inhibitory parameters}

The minimum inhibitory concentration (MIC) and minimum bactericidal concentration (MBC) of the antibacterial agents were determined using the microdilution method as described by CLSI (2012). 100 $\mu \mathrm{L}$ of sterile nutrient broth was dispensed into the 96 well microtiter plates. A serial double dilution of geometric ratio of $1 / 2$ of the $\mathrm{EO}$ was realized into the broth in the wells over a concentration range of $150 \mathrm{mg} / \mathrm{mL}$ to $2.34 \mathrm{mg} / \mathrm{mL}$ for the leaves and $400 \mathrm{mg} / \mathrm{mL}$ to $6.25 \mathrm{mg} / \mathrm{mL}$ for the resin and stem-barks and $250 \mathrm{mg} / \mathrm{mL}$ to $3.91 \mathrm{mg} / \mathrm{mL}$ for gentamicin. Overnight cultures of each strain were prepared in nutrient broth and the final concentration of each well was adjusted spectrophotometrically to $1.5 \times 10^{6} \mathrm{CFU} / \mathrm{mL}$.

Positive and negative control wells: nutrient broth + inoculum and $\mathrm{EO}+$ nutrient broth respectively were included in each test. All tests were done in triplicate and incubated at $37{ }^{\circ} \mathrm{C}$ for 24 hours. The MIC was defined as the smallest concentration of the antibacterial agent that did not allow any visible (unaided eye) color change of the medium prior to the addition of $40 \mu \mathrm{L}$ of 2,3,5-triphenyl tetrazolium chloride (TTC) at a concentration of $0.2 \mathrm{mg} / \mathrm{L}$ further incubated for 30 minutes at $37{ }^{\circ} \mathrm{C}$.

The MBC was assessed by subculture. $50 \mu \mathrm{L}$ of the content of wells (unrevealed) corresponding to concentrations $\geq$ MIC were transferred unto $150 \mu \mathrm{L}$ of fresh nutrient broth. The plates were incubated at $37{ }^{\circ} \mathrm{C}$ for 48 hours. $40 \mu \mathrm{L}$ of TTC was used to reveal bacterial growth in each well. The MBC was regarded as the lowest concentration of each antibacterial substance that did not allow any noticeable color change from golden yellow to red.

\section{RESULTS AND DISCUSSION}

\section{Extraction of essential oil}

Resin gave the highest yield of $11.47 \%$ compared to those of the stem-barks and leaves which were $0.07 \%$ and $0.01 \%$ (w/w) respectively. In a previous study by Obame et al., 2008, the resin oil from Gabon gave limpid oil with a yield of $6.8 \%(\mathrm{w} / \mathrm{w})$. The fact that the resin used in this work was fresh as oppose to that used by the aforementioned authors (who bought the resin from the herbarium, probably an old one) could be the reason behind this difference in yields. In another survey carried out by Silou et al. (2013), a maximum yield of $0.5 \%$ was obtained from the hydrodistillation of eight samples of $D$. edulis leaves. The difference in yield may be related to the harvest period, varied agro-climatic conditions of the regions, plant species.

\section{Chemical compositions}

Results of the chemical analysis by GC and GC-MS showed different compositions (Table 1) dominated by $p$-cymene (30.32\%), $\alpha$-thujene $(28.58 \%), \alpha$-phellandrene $(27.14 \%)$ and $\beta$ phellandrene $(10.16 \%)$ in the resin EO. The stem-barks EO had as abundant components $p$-cymene $(35.14 \%)$, trans-carveol (22.60\%), $\alpha$-thujene $(14.86 \%), \beta$-phellandrene $(8.65 \%)$ and $\beta$ elemene $(5.22 \%)$ whereas the leaf EO was distinct in elemol (29.22\%), caryophyllene oxide (15.26\%), trans-carveol (11.80\%) and spathulenol $(6.28 \%)$ as the major compounds. The resin and stem-barks EO exhibited some qualitative resemblance ( $\alpha$-thujene, $\beta$-phellandrene, and $p$-cymene) although there was a difference in levels of these compounds. The main difference was the presence of $\alpha$-phellandrene in the resin EO as a major component but a minor compound in the stem-barks EO.

These findings do not concord with that of Obame et al. (2008) who reported 24 components from the resin essential oil from Gabon dominated by sabinene (21.8\%), terpinene-4-ol (19.8\%), $\alpha$-pinene (17.5\%) and $p$-cymene (11.3\%). Moreover, Burkill (1994) found out that under steam distillation, resin yields a peppery EO rich in sabinene, $\beta$-phellandrene and limonene. This mismatch of data could be ascribed to the genetic variability of the plant species.

Onocha et al. (1999) argues that terpinen-4-ol (25.6\%) and a mixture of $\alpha$-pinene and $\alpha$-thujene $(25.2 \%)$ are the predominant components of the stem-barks EO. According to them, $\beta$-caryophyllene (26.4\%) is the dominant constituent of the leaves EO from Nigeria. A similar result has also been published from Nigeria by Silou et al. (2013) who notice that the leaves EO of $D$. edulis contains mostly sesquiterpenes among which is $\beta$ caryophyllene (3-10\%). The marked differences in the chemical constituents of the same plant across countries might be due to the 
varied adaptive metabolism of the plants, season (for example before or after flowering) and time of day when harvesting is done (Perry et al., 1999).

Table 1: Quantitative and qualitative chemical composition of the essential oils of D. edulis

\begin{tabular}{|c|c|c|c|c|}
\hline \multirow[b]{2}{*}{$\begin{array}{l}\text { Kovalt's } \\
\text { Index }\end{array}$} & \multirow{2}{*}{$\begin{array}{c}\text { Compounds (In order of } \\
\text { elution) }\end{array}$} & \multicolumn{3}{|c|}{ Essential oil composition (\%) } \\
\hline & & Resin & $\begin{array}{l}\text { Stem- } \\
\text { barks }\end{array}$ & Leaves \\
\hline \multicolumn{2}{|c|}{ Hydrocarbon monoterpenes } & 97.64 & 68.47 & 5.37 \\
\hline 944 & $\alpha$-thujene & 28.58 & 14.86 & 1.34 \\
\hline 955 & $\alpha$-pinene & 0.52 & 0.07 & / \\
\hline 957 & Camphene & / & 0.77 & I \\
\hline 984 & $\alpha$-phellandrene & 27.14 & 1.62 & / \\
\hline 989 & $\beta$-phellandrene & 10.16 & 8.65 & 0.64 \\
\hline 995 & $\beta$-pinene & 0.09 & 1.04 & / \\
\hline 1024 & 3-carene & 0.49 & 0.93 & 2.46 \\
\hline 1043 & p-cymene & 30.32 & 35.14 & / \\
\hline 1064 & $p$-mentha-6,8-diene (R)-(+) & 0.24 & 2.71 & 0.93 \\
\hline 1096 & Cis-ocimene & 0.10 & 1.24 & / \\
\hline 1122 & $Y$-terpinene & I & 0.26 & I \\
\hline 1131 & Mentha-2,4-(8)-diene & / & 1.18 & / \\
\hline \multicolumn{2}{|c|}{ Oxygenated monoterpenes } & 2.26 & 24.05 & 14.59 \\
\hline 1150 & Linalool & / & 0.90 & / \\
\hline 1152 & Pinocarveol & / & 0.04 & / \\
\hline 1187 & Trans-carveol & 1.81 & 22.60 & 11.80 \\
\hline \multirow[t]{2}{*}{1198} & $p$-menth-1-en-9-ol & 0.45 & 0.51 & 2.79 \\
\hline & Sesquiterpenes & 0.10 & 7.33 & 4.34 \\
\hline 1202 & $\beta$-elemene & 0.10 & 5.22 & 1.0 \\
\hline 1209 & (E)-caryophyllene & / & 0.45 & I \\
\hline 1218 & $\alpha$-guaiene & / & 0.48 & I \\
\hline 1265 & $\alpha$-humulene & / & 0.46 & I \\
\hline 1387 & Germacrene D & / & 0.37 & I \\
\hline 1395 & $\beta$-selinene & / & 0.17 & / \\
\hline 1436 & $\alpha$-selinene & / & 0.18 & 3.34 \\
\hline \multicolumn{2}{|c|}{ Oxygenated sesquiterpenes } & 0.00 & 0.15 & 64.99 \\
\hline 1444 & Elemol & / & 0.15 & 29.22 \\
\hline 1484 & 2-nerolidol & / & / & 2.09 \\
\hline 1514 & Spathulenol & / & I & 6.28 \\
\hline 1541 & Trans-isolongifolanone & / & / & 1.09 \\
\hline 1545 & $Y$-eudesmol & / & / & 1.16 \\
\hline 1564 & $\alpha$-eudesmol & I & / & 1.74 \\
\hline 1570 & Caryophyllene oxide & I & I & 5.10 \\
\hline 1590 & Ischwarone & I & I & 15.26 \\
\hline \multirow[t]{2}{*}{1610} & $\begin{array}{l}\text { 14-hydro-4,5- } \\
\text { dihydrocaryophyllene }\end{array}$ & I & I & 3.05 \\
\hline & Diterpenes & 0.00 & 0.00 & 10.47 \\
\hline 1711 & Cubitene & / & / & 4.34 \\
\hline 1714 & Laurenene & I & I & 0.99 \\
\hline 1724 & Rimuene & I & I & 3.67 \\
\hline 1771 & Epi-laurenene & 1 & I & 1.47 \\
\hline
\end{tabular}

\section{Antibacterial activity}

The susceptibility pattern and inhibition parameters of the tested organisms to the EO are indicated below (Table 2 and 3). It was noticed that the most active EO was that of the leaves which exhibited an appreciable activity. Although the active only on $80 \%$ of the strains with an inhibition diameter of $13.33 \pm 0.58$ $\mathrm{mm}$ and MIC of $18.78 \mathrm{mg} / \mathrm{mL}$ on Bacillus cereus. The least active EO was that of resin which demonstrated a considerable activity with an inhibition diameter of $10.33 \pm 0.58 \mathrm{~mm}$ and MIC of 200 $\mathrm{mg} / \mathrm{mL}$ on $E$. coli which was sensitive to only $66.7 \%$ of the EO. The ratio of MBC/MIC revealed that the leaves EO was bactericidal on B. cereus, Shigella spp $(\mathrm{MBC} / \mathrm{MIC}=1)$ and $S$. typhi $(\mathrm{MBC} / \mathrm{MIC}=2)$, the stem-barks oil was also bactericidal on $S$. typhi; E. coli; S. aureus and Shigella spp $(\mathrm{MBC} / \mathrm{MIC}=2)$ but bacteriostatic on $B$. cereus $(\mathrm{MBC} / \mathrm{MIC}=4)$ while gentamicin was bactericidal $(\mathrm{MBC} / \mathrm{MIC}=1)$ on all the five strains.

Table 2: Inhibition zone diameters of the essential oils against the tested bacteria using the well variant assay.

\begin{tabular}{lccccc}
\hline STRAINS & B. cereus & S. typhi & S. aureus & Shigella spp. & E. coli \\
\hline E.O/GEN. & $\mathrm{IZ} \varphi \pm \mathrm{sd}$ & $\mathrm{IZ} \varphi \pm \mathrm{sd}$ & $\mathrm{IZ} \varphi \pm \mathrm{sd}$ & $\mathrm{IZ} \varphi \pm \mathrm{sd}$ & $\mathrm{IZ} \varphi \pm \mathrm{sd}$ \\
& $(\mathrm{mm})$ & $(\mathrm{mm})$ & $(\mathrm{mm})$ & $(\mathrm{mm})$ & $(\mathrm{mm})$ \\
Leaves & $13.33 \pm 0.58$ & $10.00 \pm 1.00$ & $12.33 \pm 0.58$ & $8.00 \pm 1.00$ & $\mathrm{ND}$ \\
Stem-bark & $10.67 \pm 0.58$ & $9.00 \pm 1.00$ & $11.33 \pm 0.58$ & $9.33 \pm 0.58$ & $10.67 \pm 0.58$ \\
Resin & $10.00 \pm 1.00$ & $9.00 \pm 0.00$ & $7.67 \pm 0.58$ & $9.33 \pm 0.58$ & $10.33 \pm 0.58$ \\
Gentamicin & $30.00 \pm 1.73$ & $23.00 \pm 1.00$ & $24.33 \pm 0.58$ & $26.00 \pm 1.00$ & $22.00 \pm 1.00$ \\
\hline
\end{tabular}

B. cereus $=$ Bacillus cereus E . coli $=$ Escherichia coli $;$ Gen $=$ gentamicin $\mathrm{Iz} \varphi=$ inhibition zone diameter; S. typhi= Salmonella typhi; $\mathrm{sd}=$ standard deviation; S. aureus $=$ Staphylococcus aureus.

Table 3: Inhibition parameters of the essential oils and gentamicin on the tested bacteria.

\begin{tabular}{|c|c|c|c|c|c|}
\hline \multirow[b]{2}{*}{ Strains } & \multirow{2}{*}{$\begin{array}{c}\text { Inhibitory } \\
\text { Parameters } \\
(\mathrm{Mg} / \mathrm{Ml})\end{array}$} & \multicolumn{3}{|c|}{ Essential Oil } & \multirow[b]{2}{*}{ Genta. } \\
\hline & & Resin & $\begin{array}{l}\text { Stem- } \\
\text { Barks }\end{array}$ & Leaves & \\
\hline \multirow[t]{3}{*}{ B. cereus } & $\mathrm{MIC}$ & 200 & 50 & 18.75 & 0.03 \\
\hline & MBC & ND & 200 & 18.75 & 0.03 \\
\hline & MBC/MIC & ND & 4 & 1 & 1 \\
\hline \multirow[t]{3}{*}{ S. typhi } & MIC & 200 & 50 & 18.75 & 0.03 \\
\hline & MBC & ND & 100 & 37.5 & 0.03 \\
\hline & MBC/MIC & ND & 2 & 2 & 1 \\
\hline \multirow[t]{3}{*}{ S. aureus } & MIC & 200 & 50 & 18.75 & 0.03 \\
\hline & $\mathrm{MBC}$ & ND & 100 & ND & 0.03 \\
\hline & MBC/MIC & ND & 2 & ND & 1 \\
\hline \multirow[t]{3}{*}{ Shigella spp. } & MIC & 200 & 50 & 18.75 & 0.03 \\
\hline & MBC & ND & 100 & 18.75 & 0.03 \\
\hline & MBC/MIC & ND & 2 & 1 & 1 \\
\hline \multirow[t]{3}{*}{ E. coli } & MIC & 200 & 50 & I & 0.03 \\
\hline & MBC & ND & 100 & I & 0.03 \\
\hline & $\mathrm{MBC} / \mathrm{MIC}$ & ND & 2 & I & 1 \\
\hline
\end{tabular}

B. cereus $=$ Bacillus cereus $;$ E coli $=$ Escherichia coli $;$ Genta = gentamicin; $\mathrm{MBC}=$ Minimum Bactericidal Concentration; $\mathrm{MIC}=$ Minimum Inhibitory Concentration; ND= Not Determined; S. typhi= Salmonella typhi $;$ S. aureus= Staphylococcus aureus

The observed activity is probably due to the synergistic interaction between the compounds within the EO endowed with antibacterial activity just to cite hydrocarbon monoterpenes, oxygenated monoterpenes, (oxygenated) sesquiterpenes (Dorman and Deans, 2000).

These compounds act by inducing membrane protein and lipid denaturation, inhibition of DNA replication and perturbation of membrane proton motive force, loss of energy substrate (glucose, ATP), leading directly to the lysis of bacteria (cytolysis) and therefore to its death. Another mechanism of action could be the inhibition of amylase and protease production which halts the toxin production by the bacteria, electron flow and result in coagulation of the bacterial cell content (Bakkali et al., 2008; Nazzaro et al., 2013). The bactericidal activity of the leaves EO could be attributed to the synergistic effects of the major compounds and those represented in trace amounts such as 3carene, $\alpha$-thujene which have been reported to have some antimicrobial actions (Dorman and Deans, 2000). Besides, the 
antibacterial property of caryophyllene oxide has been reported previously (Magiatis et al., 2002).

Caryophyllene oxide is well recognize as a stabilizer in foodstuffs, drugs and cosmetics and also shows growth inhibiting activity against dermatophytes (Yang et al., 1999). The resin EO was found to be fairly similar to the stem-barks EO; an observation not unexpected given that both EO were obtained from the same source. Their moderate activity could be explained by their high content in hydrocarbon monoterpenes. It has been demonstrated that most terpenes do not possess high inherent antimicrobial activity. For instance, p-cymene, one of the most important components of thyme EO, does not show antimicrobial activity against many Gram-negative pathogens (Bagamboula et $a l ., 2004)$. Other terpenes, such as limonene, $\alpha$-pinene, $\beta$-pinene, $\gamma$ terpinene, $\delta$-3-carene, sabinene and $\alpha$-terpinene show a very low or no antimicrobial activity against some bacteria (Dormans and Deans, 2000). The results of this study do not concord with that in the literature documented by Obame et al., 2008 who holds that resin EO is characterize by terpinene-4-ol (19.8\%), $\alpha$-pinene $(17.4 \%)$ that confer the oil a stronger and broader antimicrobial activity.

The disparity in reports could be attributed to the variation in the harvesting period, differences in soil composition and probably due to differences in the genetic variability between the plants used.

\section{CONCLUSION}

This work had as main objective to valorize the EO of $D$. edulis by establishing their chemical composition and assess their in vitro antibacterial activity. Hydrodistillation of the botanical material showed that the resin was the richest in EO whereas the leaves were the least. The chemical analyses revealed the resin, leaves and stem-barks EO contained 12, 21, 24 components respectively. The resin and stem-barks EO were dominated by hydrocarbon monoterpenes while the leaf EO was rich in a mixture of oxygenated monoterpenes, oxygenated sesquiterpenes and diterpenes. The leaf EO was the most active oil meanwhile the resin EO was the least active according to the susceptibility test and microdilution assay. B. cereus was the most sensitive strain to the EO while E. coli was resistant to the leaf EO. The leaf and stem-barks EO were bactericidal on most of the strains while the resin EO was bacteriostatic on all strains at a rather higher concentration. Summarily, the Gram positive bacteria were more susceptible to the toxic effects of the EO than their Gram negative counterparts. This shows that $D$. edulis EO have antibacterial activity which if well harnessed can be used in drug formulations against the usual gastrointestinal pathogens.

\section{REFERENCES}

Adams, R. 2012. Identification of essential oil components by gas chromatography/mass spectrometry, $4^{\text {th }}$ edition. Allured Publishing Co. Carol Stream, Illinois.

AFNOR. 2007. Huile essentielles echantillonnage. Normes internationals NF ISO 2212 du 20 Mai NFT 75 A.
AFSSAPS. 2008. Recommandations relatives aux critères de qualités des huiles essentielles, $18 \mathrm{p}$

Agnaniet, H., Agrebi, A., Bikanga, R., Makani, T., Lebibi, J., Casabianca, H., Monere, A., Menut, C. Essential oils of Plecthranthus tenuicaulis leaves from Gabon, source of (R), (E)-Epoxyocimene. An unusual chemical composition within the Genus Plecthranthus. Natural Product Communications, 2011; 6(3): 409-416.

Ahmad, I., Mahmood, Z., Mohammad, F. Screening of some Indian medicinal plants for their antimicrobial propreties. Journal of Ethnopharmacology, 1998; 62:183-193.

Ajibesin, K., Essien, E., Adesanya, A. Antibacterial constituents of the leaves of Dacryodes edulis. African Journal of Pharmacy and Pharmacology, 2011; 5(15): 1782-1786.

Ayuk, E., Duguma, B., Franzel, S., Kangué, J., Mollet, M., TikiManga, T., Zekeng, P. Uses, management and economic potential of Dacryodes edulis (Burseraceae) in the humid lowlands of Cameroon. Economic Botany, 1999; 53(3): 292-301.

Bagamboula, C., Uyttendaele, M., Debevere, J. Inhibitory effect of thyme and basil essential oils: carvacrol, thymol, estragol, linalool and p-cymene towards Shigella sonnei and S. flexneri. Food Microbiology, 2004; $21: 33-42$.

Bakkali F., Averbeck S., Averbeck D., Idaomar M. Biological effects of essential oils-A review. Food and chemical toxicology, 2008; 46: 446-475.

BioactivPlantBase. 2015. Available on line at: http// BioactifPlantBase. Access on: 30/09/2015.

Burkill, H. The Useful Plants of West Tropical Africa.Vol. 1, Families A-D. Royal Botanic Gardens, Kew 2nd Ed. 1985; Pp.18-34.

Burkill, H. Useful plants of West Tropical Africa. Vol. 2, Families E-I. Royal Botanical Gardens, Kew 2nd. Ed. 1994; pp.1-17

Clark, A. Natural products as source of new drugs. Pharmaceutical research, 1996; 13:1133-1141.

CLSI. Methods for antimicrobial susceptibility testing of anaerobic bacteria. Approved standards-ninth edition. Wayne PA: Clinical Laboratory Standards Institute, M11-A8, 2011; 32 (5).

CLSI. Methods for dilution antimicrobial susceptibility tests for bacteria that grow aerobically. Approved standards-ninth edition. Wayne PA: Clinical Laboratory Standards Institute, M07-A9, 2012; 32 (2).

Dorman, H., Deans, S. Antimicrobial agents from plants: Antibacterial activity of plant volatile oils. Journal of Applied Microbiology, 2000; 88: 308-316.

Ghost, T., Mithy, T., Swain, P., Bose, A. Anthelmintic and antimicrobial activity of Enlrydra fluctuans Lour aerial parts. Pharmacognosy, 2008; 11 (1): 204-208.

Hulin, V., Mathot, A., Mafart, P., Dufosse, L. Les propriétés antimicrobiennes des huiles essentielles et composés d'arômes. (Antimicrobial properties of essential oils and flavour compound). Sciences des aliments, 1998 ; 18(6): 563-582.

IVAC 2013. Pneumonia and Diarrhea Progress Report. International Vaccine Access Center, Johns Hopkins Bloomberg School of Public Health Rangos Bldg, Suite 600855 N. Wolfe Street Baltimore, MD 21205.

Kouitcheu, L., Tamesse, J., Kouam, J. The anti-shigellosis activity of the methanol extract of Picralima nitida on shigella dysenteriae type 1 induced diarrheoa in rats. BMC Complementary and Alternative Medicine, 2013; 13:211-222.

Magiatis, P., Skaltsounis, A., Chinou, I., Haroutounian, S. Chemical composition and in vitro antimicrobial activity of the essential oils of three Greek Achillea species. Z. Nature for school, 2002; 57(c): 287-290.

Nazzaro, F., Fratianni, F., De Martino, L., Coppola, R., De Feo, V. Effect of essential oils on pathogenic bacteria. Pharmaceuticals, 2013; 6:1451-1474.

Ndoyé, C. Etude chimique et évaluation des propriétés antiradicalaires et antioxydantes des huiles essentielles d'espèces aromatiques tropicales en Province Est du Cameroun. Thèse de doctorat troisième cycle, Université de Montpellier II, 2001 ; 319p.

Nyegue, M. Propriétés chimiques et biologiques des huiles essentielles de quelques plantes aromatiques et / ou médicinales du 
Cameroun: évaluation de leurs activités antiradicalaires, antiinflammatoires et antimicrobiennes. Thèse de doctorat de troisième cycle. Université de Monpéllier II, 2006 ; 194p.

Obame, L., Edou, P., Bassolé, I., Koudou, J., Agnaniet, H., Eba, F., Traore, A. Chemical composition, antioxidant and antimicrobial properties of the essential oil of Dacryodes edulis (G.Don) H. J. Lam from Gabon. African Journal of Microbiology Research, 2008; 2:148-152.

Onocha, P., Olusegun, E., Oyeleye, Into. Essential oils of Dacryodes edulis (G.Don) H.J Lam (African pear). Flavour and Fragrance Journal, 1999; 14 (2):135-139.

Perry, N., Anderson, R., Brennan, N., Douglas, M., Heaney, A., McGimsey, J., Smallfield, B. (1999). Essential oils from Dalmation sage (Salvia officinalis L.): variations among individuals, plant parts, seasons and sites. Journal of Agricultural and Food Chemistry, 1999; 47: 20482054 .

Silou, T., Aubin, N. L., Goteni, S., Bopoundza, C., Mckany, A.R., Figueredo, G., Chalchat, J-C. Variability of the essential oils from the leaves of Safou tree: Dacryodes edulis (G. Don) H.J. Lam in Congo Brazaville. Journal of Essential Oil Bearing Plant, 2013; 15 (1) 108-115.

Valgas, C., De Souza, S., Smânia, E. Smânia, A. Screening methods to determine antibacterial activity of natural products. Brazilian Journal of Microbiology, 2007; 38: 369-380.
WHO. 2006. Diarrhees. http//: www.who.int/topics/diarrhoea/fr. [Accessed on 17 July 2015]

World Health Organisation. Summary of WHO guidelines for the assessment of herbal medicines. Herbal Gram, 1993; 28:13-14.

Yang, D., Michel, L., Chaumont, J-P., Millet-Clerc, J. Use of caryophyllene oxide as an antifungal agent in an in vitro experimental model of onychomycosis. Mycopathologia, 1999; 148: 79-82.

\section{How to cite this article:}

Sara Honorine Riwom, Florentine Marie chantal Ndoyé Foe, Maximilienne Ascension Nyegue, Reskingjoe Ambe Wanki, François-Xavier Etoa. Chemical Composition and in Vitro Antibacterial Activity of the Essential Oils of the Leaves, Resin and Stem-Barks of Dacryodes Edulis (G. Don) H. J Lamgrowing in Cameroon on Diarrhea Associated Strains. J App Pharm Sci, 2015; 5 (10): 006-011. 